\title{
TCOM \\ Science communicators intimidated: researchers' freedom of expression and the rise of authoritarian populism
}

\section{Esa Väliverronen and Sampsa Saikkonen}

Abstract

Keywords

DOI

Introduction
In this article, we explore scientists' freedom of expression in the context of authoritarian populism. Our particular case for this analysis is Finland, where the right-wing populist Finns Party entered the government for the first time in 2015. More recently, after leaving the government in 2017, the party has been the most popular party in opinion polls in 2021. We illustrate the current threats to Finnish researchers' freedom of expression using their responses on three surveys, made in 2015, 2017 and 2019. We focus on politically motivated disparagement of scientists and experts, and the scientists' experiences with online hate and aggressive feedback. Further, we relate these findings to the recent studies on authoritarian populism and science-related populism. We argue that this development may affect researchers' readiness to communicate their research and expertise in public.

Science and media

https://doi.org/10.22323/2.20040208

Submitted: 29th January 2021

Accepted: 4th May 2021

Published: 21st July 2021

Restrictions to academic freedom and researchers" public expression have become more globally prominent in the last two decades. This is not just a problem for dictatorial states - the rise of authoritarian populism has also fuelled the phenomenon throughout the world, including Europe and the United States.

Scholars at Risk (SAR) is an international organisation that monitors violations of academic freedom and freedom of expression around the world. According to the recent report [Scholars at Risk, 2020] "(a)ttacks on scholars, students, staff, and their institutions occur with alarming frequency. Around the world, state and non-state actors, including armed militant and extremist groups, police and military forces, government authorities, off-campus groups, and even members of higher education communities, among others, carry these attacks". In many countries pressures on academic communities around the world have increased as a result of the COVID-19 pandemic". Thus, the pandemic has also increased public questioning of expert institutions [Väliverronen, Laaksonen et al., 2020]. 
The rise of authoritarian populism [Norris and Inglehart, 2019] has not only posed threats to the media and freedom of expression; it also means that the 'spaces for critical inquiry are shrinking' [Grimm and Saliba, 2017, p. 43]. According to Norris and Inglehart, authoritarian populists favour strong governance preserving order and security against perceived threats such as immigrants, even at the expense of democratic norms such as freedom of the media, human rights and civil liberties. With the concept, Norris and Inglehart refer broadly to right-wing populist parties and leaders throughout the world who have gained popularity with their anti-immigration and anti-liberal policies and nativist ideologies.

Universities and researchers are particularly vulnerable to this development, since the world of academia is largely funded and regulated by the state [Butler, 2017, p. 857]. According to Norris and Inglehart, during the 2010s, we have witnessed the rise and electoral success of authoritarian populist parties in numerous countries, including Turkey, Hungary, Poland and the United States. Further, Mede and Schäfer [2020] propose to take a closer look on "science-related populism" in order to analyse the emerging challenges for science communication and science-society relations in general. In the populist discourse, science and science-based experts are increasingly represented as "the academic elite" [Mede and Schäfer, 2020, p. 8] or "corrupt insiders-club" [Ylä-Anttila, 2018, p. 372] promoting liberal values.

Populists have particularly criticized scientists and public experts involved in environmental research such as climate change [Mede and Schäfer, 2020; Saarinen, Koivula and Keipi, 2020] and issues like immigration, multiculturalism or sex and gender [Ylä-Anttila, 2018; Väliverronen and Saikkonen, 2020]. One of the prime examples of the criticism against liberal values is Hungary where Orbán's government issued a decree that aimed to eliminate gender studies programmes at all Hungarian universities by September 2019. The official argument was that gender studies programmes were not economically viable; the government also issued an official statement, claiming that the Hungarian government is of the clear view that people are born either men or women. They lead their lives the way they think best, but beyond this, the Hungarian state does not wish to spend public funds on education in this area [qtd in Scholars at Risk, 2018, p. 44].

Restrictions to academic freedom and researchers' freedom of expression have traditionally been linked to state censorship, which seeks to prevent a matter from being disclosed because it is considered harmful or problematic [Post, 1998; Post, 2012]. Another major source of restrictions arise from industry influence over science and its public communication. Such restrictive industrial pressure can involve, for example, attempts to suppress the communication of research findings, to influence the direction and scope of research, and to instill doubt towards findings. These types of influencing by industrial actors restrictively affect scientists and typically occur regarding areas of research, such as chemical, environmental and pharmaceutical research, that bear relevance to the industries' interests [e.g. Martin, 1999; Krimsky, 2003; Michaels, 2008; Oreskes and Conway, 2011].

Direct censorship in democratic societies rarely occurs, but indirect attempts to silence researchers form a grey area that has been, thus far, given scant attention. However, it is known from previous research that limiting academic freedom and researchers' freedom of expression is done indirectly through, for example, 
complaints, funding refusals, career or employment restrictions and blackmail [see, e.g., Martin, 1999; Martin, 2001; Kuehn, 2004; Delborne, 2016; Hoepner, 2017]. A typical consequence of these efforts to exert control is the self-censorship of researchers, who usually stop researching sensitive topics, stop publishing research on sensitive topics or remain silent in public arenas about issues that are politically sensitive.

We argue that academic freedom and scientists' freedom of expression mean more than the mere absence of open control mechanisms and censorship [Väliverronen and Saikkonen, 2020]. They depend also on the political culture and the freedom of public debate. The concept of suppression refers to more subtle actions that may lead to self-censorship in researchers. Thus, direct censorship is not the only way to control researchers. Kuehn defines suppression as something that "seeks to prevent the creation of certain unwelcome data or theories, or, alternatively, to deter or block the dissemination of unwelcome data or theories that already exist" [Kuehn, 2004, p. 335]. More specifically, suppression involves efforts to withdraw research money, deny employment appointments and block publications and presentations. This is carried out in different ways, including through publication restrictions and legal sanctions.

The media has become an important arena where struggles over the symbolic legitimacy of scientific knowledge and expert authority take place [e.g. Weingart, 1998; Weingart, 2012; Arnoldi, 2007; Väliverronen and Saikkonen, 2020;

Väliverronen, 2021]. In public life, scientists and science-based experts are constantly challenged, particularly on various social media platforms. Moreover, in social media scientists and their claims are likely to face attacks, which can have an effect on their perceived credibility and integrity [Gierth and Bromme, 2020]. While scientists have traditionally been suppressed by authoritarian governments [e.g. Grimm and Saliba, 2017; Scholars at Risk, 2017; Scholars at Risk, 2018], the current movement against active and public scientists is increasingly coming from diverse political activists and groups, industrial lobbyists, think tanks and ordinary citizens in public arenas [e.g. Martin, 2001; Kuehn, 2004; Lewandowsky, Mann et al., 2016; Väliverronen and Saikkonen, 2020].

In this article, we analyze researchers' freedom of expression in the context of authoritarian populism. The particular case for this study is Finland, where the right-wing populist Finns Party entered the government for the first time in 2015, after becoming second biggest party in the elections. Since the party left government in 2017, it has been the biggest or second biggest party in opinion polls. The leading figures of the Finns Party and some of its supporters are particularly active in social media challenging established political parties, national institutions, mainstream media and academics [e.g. Hatakka, 2017; Ylä-Anttila, 2018; Saarinen, Koivula and Keipi, 2020] causing social media furores, which are picked up and extended by mainstream media. Thus, right-wing populists are skillfully taking advantage of the phenomenon Wodak [2015, p. 238] calls the "right-wing perpetuum mobile", where populists tease the liberal media with poignant and infuriating arguments in gaining attention for their political agenda. These arguments are targeted not only against liberal politicians but also increasingly against academics who are active public debates, particularly on immigration, multiculturalism, gender and sexuality, social policy or environmental issues [McDonald, Barriault and Merritt, 2020; Väliverronen and Saikkonen, 2020]. 
We analyze the current threats to scientists' freedom of expression through data gathered from three public surveys of Finnish researchers in 2015, 2017 and 2019 regarding the feedback they receive when communicating their research and expertise in public. A central theme in these surveys was researchers' freedom of expression and the type of feedback they receive after making public commentaries based on their research. Particularly the second survey made in 2017, reflected strong concerns about the "anti-science sentiment" in public discourse. Some respondents felt that aggressive feedback and online hate was causing of self-censorship among scientists. Thus, they decided to withdraw from their role as public communicators.

Authoritarian populism and the critique against 'liberal academic elite'
During the last two decades, we have witnessed the rise and electoral success of populist leaders and parties worldwide, such as in U.S.A., Brazil, and in Europe, including the Netherlands, Austria, Germany, Italy, Turkey, Hungary, Poland, the Nordic countries, among others. Populist movements have challenged established parties and power structures with their policies against "corrupted elites", "Brussels bureaucrats", and "arrogant liberals". Perhaps the most striking global examples of this development were the Brexit vote in 2016 and the election of Donald Trump to the White House [Norris and Inglehart, 2019].

There are many kinds of populism — from extreme right to the left — and many ways to define what populism actually is - from a distinct ideology to a rhetorical style [e.g. Mazzoleni, 2003; Laclau, 2005; Mudde, 2007; Mudde, 2017; Herkman, 2016] but here we will focus on authoritarian populism [Norris and Inglehart, 2019], which tries to grasp some of the most common features of right-wing populism that has been on the rise particularly on the 2010s. Norris and Inglehart define authoritarian populism as a political style where nationalistic populistic rhetoric is combined with an authoritarian style of government:

Norris and Inglehart briefly discuss the violations against press freedom and freedom of expression in relation to authoritarian populism, but they do not address academic freedom or scientists' freedom of expression as such. However, we believe that the rise of authoritarian populism is a relevant context through which to understand the recent threats to academic freedom and freedom of expression. In countries such as Turkey [see, e.g. Özkirimli, 2017, p. 853; Scholars at Risk, 2017; Scholars at Risk, 2018; Aktas, Nilsson and Borell, 2019] and Hungary [e.g. Ignatieff, 2018; Scholars at Risk, 2018], the limitations imposed by authoritarian populist governments on freedom of the press and freedom of expression go hand in hand with restrictions to academic freedom. The same can be said for the attacks on the mainstream media, environmental science and academic experts in the United States [e.g. Cole, 2017; Collins et al., 2020], where authoritarian populism has gone mainstream. 
The relation between right-wing populism and science has been addressed only recently [e.g. Collins et al., 2020; Mede and Schäfer, 2020]. Mede and Schäfer [2020, pp. 3-7] propose that the relation between populism and science should be conceptualized in relation to political populism, particularly to its basic distinction between "the people" versus "the elite", to the "participatory turn" criticising the weaknesses of liberal representative democracy and in relation to alternative epistemologies, or counter-knowledge promoted by the critics of established scientific knowledge. Science-related populism makes a distinction between "the ordinary people" and "the academic elite", assuming that the latter is somehow morally inferior [Mede and Schäfer, 2020, p. 9].

In previous studies it has been observed that especially social media provide populists the opportunity to spread such antagonistic discourse by circumventing gatekeepers, such as journalists, thus being able to more directly address citizens dissatisfied with established elites and institutions and presenting themselves as uncorrupted "non-elites" [e.g. Engesser, Fawzi and Larsson, 2017; Gerbaudo, 2018]. For populists, social media platforms therefore provide a space to attack also researchers' claims and viewpoints by portraying academics as a corrupt academic elite. As a communicative environment, social media therefore affords authoritarian populists to more easily portray and attack researchers, as well as to address such attacking discourse more directly to different audiences.

However, it is debatable whether right-wing populism should be called simply as an anti-science movement. Instead, their relation to established science varies in different contexts such as climate change, vaccinations, alternative medicine, immigration, multiculturalism etc. In his study on two Finnish right-wing online forums, partly related to the popular the Finns Party, Ylä-Anttila [2018] described populist discourses related to science and established experts as an alternative "populist epistemology". Although some of the common discourses on these forums represented somewhat typical science denial (climate change) or conspiracy theories (medicine), in other contexts such as culture and society (multiculturalism, immigration etc.), they advocated "a particular kind of objectivist counter-expertise" [Ylä-Anttila, 2018, p. 358]. For instance, they criticized studies and experts representing feminism, gender or ethnicity as non-positivist and non-rational, thus they were favouring statistical methods and particular notions of objectivity.

Thus, authoritarian populists are particularly attacking 'liberal elites', including academics representing liberal values. In Europe this has been recently visible in Hungary. The restrictions to the academic freedom and scientists' freedom of expression in Hungary during 2010s show concretely the collision between authoritarian populist values and academic freedom. The Central European University (CEU) has become a symbol of the academic freedom and freedom of expression. Hungarian-American entrepreneur and philanthropist George Soros founded the university in Budapest, and he has long been an object of derision for Prime Minister Viktor Orbán. In 2017, a new university law came into force in Hungary that was specifically aimed at the CEU [Ignatieff, 2018]. Since then, the university has been trying to negotiate its position, but its operating conditions have weakened. In December 2018, the university announced that it would transfer its operations to Vienna because its situation in Budapest was becoming impossible. 
The Hungarian government has also proposed challenges to other higher education institutions and research centres. In July 2019, the Hungarian government took the Hungarian Academy of Sciences into its control. The country's Academy of Sciences which had enjoyed relative independence consists of a society of distinguished scientists and intellectuals, a research network of 15 institutes and 150 research groups comprising around 3,000 scientific researchers.

These actions have been praised by some representatives of the Finns Party. After the decision to eliminate gender studies from Hungary in 2018, the vice chairman of the party, Laura Huhtasaari commented: "Hungary is a pioneer. The university must not be harnessed by the value liberal elite as a platform for harmful social experimentation". [3]

The Finns Party was founded in 1995. In the 2015 election, the party received 17.7 percent of the votes, making them the parliament's second-largest party. The roots of the party lie in Finnish agrarian populism, which has distinct anti-elitist and conservative tones. The party's predecessor, the Finnish Rural Party, had twice participated in the government in the 1980s. While the Finnish Rural Party and the Finns Party prior to 2010 occupied a centre-left political position, in the last ten years, the party has moved to the right and possesses numerous ideological characteristics that are similar to other radical-right parties in Europe [Berezin, 2013; Jungar, 2016; Patana, 2020; Norris and Inglehart, 2019].

Following the parliamentary election of 2015, a coalition government consisting of Finland's three largest centre-right parties - the Centre Party, the National Coalition and the Finns Party - was formed. This marked the first time that the right-wing populist Finns Party had participated in a Finnish government. Prior to this, Finland had struggled with poor economic performance, partly due to economic stagnation after the European debt crisis. The government addressed these problems by adopting an austerity programme with cuts to government spending and reduced labour costs. A controversial measure adopted by the centre-right government was reduced public spending on education and research. This was something of a departure from the successful Finnish education system that the country is so proud of. The other cuts in the austerity programme were primarily targeted at public, social and educational arenas. For instance, cuts of 289 million euro were made to basic and secondary education, and cuts of 295 million euro were made to higher education. These cuts were implemented by merging educational units, closing down small disciplines and cutting financial aid to universities, polytechnics and the Academy of Finland [Kangas and Kalliomaa-Puha, 2017]. Thus, it is not surprising that the government became unpopular in the world of Finnish academia. Discontent with the government caused public demonstrations by academics and a one-day strike at the University of Helsinki in 2018.

Thus, from 2015 to 2019, the centre-right government was highly unpopular among Finnish academics. A reason for this mistrust, aside from the curtailment of academic freedom, was the increasing political influence of the Finns Party, who had cultivated anti-immigration and anti-intellectual sentiment in Finland. Numerous academics had earlier blamed the leaders of the Finns Party for favouring racism and hate speech. 
Already in 2010, the Finnish media had begun to publish articles about the aggressive feedback experienced by scientists conducting research in immigration, multiculturalism and racism. For instance, in spring 2013, the leading daily newspaper in Finland, Helsingin Sanomat, published an article entitled 'This is how mouths are shut'. The article was based on a small survey conducted among researchers. Many of the researchers who were interviewed for the story wanted to remain anonymous, as they 'did not want more hate mail'.

The silencing of writers and journalists in different countries has been widely publicised, but violations to researchers" freedom of expression have been largely neglected, even though the problem has existed for a long time. The writer Sirpa Kähkönen, chairman of the Finnish branch of PEN International, stated in Helsingin Sanomat in 2016: "Fear makes researchers and intellectuals start to limit their public appearances and they do not want to speak publicly about their own research".

The debate on freedom of expression in Finnish media has also re-emerged in recent years. For several years, Finland occupied first place in the World Press Freedom Index, published by RWB. However, in 2017, Finland fell to third place and then to fourth the following year. According to the RWB report, the main reasons for Finland's fall were text messages sent from Prime Minister Sipilä to a reporter working at the Finnish Broadcasting Company in autumn 2016. It appeared from the messages that Sipilä had tried to intimidate the reporter, who had just published a story on Sipilä's businesses and his family. The Council for Mass Media in Finland took a stand on the inappropriate feedback and pressure experienced by journalists and researchers in the spring of 2016:

\begin{abstract}
However, threats against the journalist's person also have wider adverse effects on the entire Finnish society. Inappropriate feedback and direct threats may reduce or completely prevent the handling of certain issues in the media. This has already been seen in the past, when some researchers have refrained from commenting on 'sensitive' topics. Conscious or unconscious self-censorship is a threat to freedom of expression and social debate and, consequently, to the entire democratic society.
\end{abstract}

Data and analytical perspective
In this article, we will illustrate the current threats to academic freedom and freedom of expression through data gathered from three public surveys of Finnish researchers regarding the feedback they received on their public role. These surveys were launched by the Committee for Public Information in Finland, which works under the Ministry of Education, and conducted in the form of online questionnaires in 2015, 2017 and 2019. The surveys were conducted as anonymous online surveys, inviting researchers from different fields to respond and asking them to disseminate the survey further. Thus, the responses are entirely self-selected, and we cannot assume any statistical representativity.

Over $60 \%$ of the surveys' respondents worked in universities, and more than $20 \%$ of them worked in state research institutes. In addition, almost $50 \%$ of the respondents were professors or senior researchers. Around 35\% of the respondents represented social sciences and $25 \%$ came from the humanities. Social scientists were also those whose had encountered harassment and threats most often, dealing with issues such as immigration, multiculturalism, racism, environmental policy or sex and gender. 
The first survey received 525 responses, 350 of which were fully completed. The second survey resulted in 255 , and the third survey in 276 , fully completed responses. These surveys included 12 items where respondents were asked to comment on the statements posed. The length of these answers varied from just a few words to 10 sentences. The total volume of the verbal material was 70 pages.

Since these surveys do not form a statistically representative sample of the Finnish researchers, we will focus on the responses to the open-ended questions in these surveys. Particularly the second survey made in 2017, reflected strong concerns about the 'anti-science sentiment' in public discourse and the increasing discontent with policies of the centre-right government. Many of the respondents made remarks on 'public hostility towards science' and aggressive feedback against public experts, by the supporters of the populist party and also by some leading politicians.

Our focus is on online hate, aggressive feedback, and politically motivated disparagement of scientists and experts. We analyse the respondents' reflections on the suppression and intimidation of academics and the role of authoritarian populist critique towards scientists as public experts. We focus particularly on those respondents who had personally experienced incidents of aggressive feedback, threats and suppression. Building on previous research about the suppression of research, research silencing, and the chilling effect, we discuss the connection between freedom of expression and academic freedom. Since these surveys were conducted as open web surveys, they were not statistically representative. Nonetheless, they provided relevant information about this phenomenon, which has been studied little in the past.

Those researchers who had experiences of aggressive feedback after their public appearances were representing 'hot topics' such as climate change and other environmental issues, vaccinations, GM foods, or nutrition and diet. Further this kind feedback was perhaps most common in some areas of social sciences and the humanities, such as multiculturalism, women's rights, sex and gender. The representatives of these fields received aggressive public criticism and vilification more often than others.

In the analysis, we qualitative analyzed the content of the respondents' responses [Silverman, 2015] regarding the feedback they have received due to acting as public experts. For this article we particularly focused on extracting and analyzing responses in the data in which the received aggressive feedback, disparagement and targeting of researchers were described by the respondents in relation to the political climate or as politically motivated or underpinned activity. Guided by our theoretical interest in this particular article, we further paid especially close attention to such content in the responses that highlighted or reflected upon the threat or problems posed towards scientists as public experts by populist commentary, undermining and attacks in society. In doing this, we also attended to scrutinizing how the authoritarian populist pressure and targeting was described to function, be directed and affect scientists as public experts in the contents of such responses. Further, we relate these findings to the recent studies on the Finns Party and its supporters' attitudes towards science [Finnish Science Barometer, 2019; Saarinen, Koivula and Keipi, 2018; Saarinen, Koivula and Keipi, 2020; Ylä-Anttila, 2018]. 
Mainstreaming populism and attacks against academics
The discontent with the centre-right government policies came out clearly in the surveys. Several responses conveyed an image of a political climate in which the depreciation and disparagement of academic researchers were common in Finnish society. Notably, many of the respondents saw this climate as being driven by some government ministers and leading politicians, and more specifically, their explicitly depreciative public comments about universities and researchers:

The recent trend where politicians join those downplaying researchers and research is dangerous because it kills the freedom of research and undermines the use of research data in decision-making (216/41/2015).

(R)esearch data is even belittled by the prime minister: the results of scientific research are equated with opinion. 'Unpleasant' results are mocked [as being] unscientific and the researchers marginalized (32/42/2017).

The increase in hate speech, I believe, leads to some degree of self-censorship, perhaps unconsciously. Also, the mocking of researchers by the government contributes to this development (29/35/2019).

Such depreciative public commentary was viewed as problematic, as it legitimises and naturalises the disregard of research evidence and researchers' views that are aired in societal discussions. According to the respondents, the ridicule of researchers was generating an atmosphere where the relevance of listening to researchers and using their research evidence is watered down, as illustrated in the quotes above.

Critique of the government among academics was fuelled by some luckless public statements made by cabinet members. The most infamous gibe against academics in this regard came from Prime Minister Sipilä during a TV talk show: "There are now too many of them [critics] in Finland to tell you what should not be done in this situation. There are all sorts of docents who say that this and this must not be done". This mocking of academics and other experts critically evaluating the economic and social policy reforms proposed by government caused widespread displeasure among academics, and the phrase was turned into a meme that was widely disseminated in public discourse: in 2016, the Finnish Association of Science Editors and Journalists gave its annual Science Communication Award to "all sorts of docents".

Many of the respondents made remarks on 'public hostility towards science' and aggressive feedback against public experts, by the supporters of the populist Finns Party:

Many scientists watch out for their words, avoid talking about certain things, even public performances. The reason is not only that the experts are undermined by the general public, but also by the government (e.g. cabinet ministers have neglected 'so-called experts' even by criticizing individuals, not only their messages). That is, even though freedom of speech exists, at the official level, attempts are made to suppress the free culture of conversation (51/41/2015).

Some political or socially active groups use hate speech, targeting and trolling in social media as tools against researchers and experts (22/42/2019)

Right-wing populist groups and the members of the Finns Party and some lay people are main problem (42/22/2017). 
Several respondents argued that mainstreaming populism has created a situation, where public debates get polarized, as illustrated in the quote below:

Polarization of the society, the conversation culture having become more heated and rougher, unwillingness to listen and try to understand the views of those who think differently has grown thinner to the extent that it has almost vanished. The shouting culture of social media has unfortunately expanded to other forums as well, to the rest of the society. Populist politics benefits from polarization and feeds it. (50/35/2019)

Moreover, regarding the manifestation of such polarization tendency it was noted in the responses how researchers can get labelled as partisans as a way to attack and question them as experts:
In social media there is spreading of false accusations and false claims about my background (e.g. political affilition) and I get vilified as a person (7/24/2017)
In certain social media sites, I get vilified and name-called, I get labelled as a supporter of a cause, and I get personal attacks (130/18/2019)

When researchers make public commentaries on hot topics such as immigration, women's rights and multiculturalism, they easily get targeted in social media. In some responses, this was mentioned as a cause of self-censorship and withdrawal from public communication among scientists:

There are certain themes about which I prefer not to talk about, that nevertheless are related to issues under discussion in society, negative feedback eats energy and I also need to think about my family [... ] (42/37/2017)

[...] Regarding some of my research topics, I have little motivation to communicate on my own initiative because they can cause unwanted attention [...] (136/37/2019)

Thus, in such instances the targeted researchers may stop researching sensitive topics, stop publishing research on sensitive topics, or remain silent in public arenas about issues that are politically sensitive.

\section{Coping with aggressive feedback and online hate}

With the rise of social media in the last decade, we have witnessed a partly novel phenomenon - namely, aggressive feedback from the general public and lay communities that is aimed at scientists. In many countries, signs of increasing public criticism of science and scientists as experts in public arenas are prevalent. This is clear in the areas of climate change research and vaccinations. Further, in the humanities and social sciences, researchers of racism, multiculturalism and immigration often receive aggressive public criticism. These issues have been debated in the social media particularly by the advocates and supporters of the Finns Party.

An important tool in this development is the website and discussion platform Hommaforum, which was established in 2008. Hommaforum was originally established in 2008 by active commentators of the popular blog by Jussi Halla-aho, the current leader of the Finns Party. According to Hatakka [2017, p. 2023] this 
online forum has significantly contributed to the "normalization of far-right populism in the public sphere". Halla-aho became the leader of the Finns Party in 2017. In the 2010s, several representatives of the Finns Party have been involved in political scandals, sometimes even using similar militant rhetoric against multiculturalism [Herkman and Matikainen, 2017; Palonen, 2018].

Aggressive feedback from the members and supporters of the Finns Party was also reflected several times in the surveys as cause for the changing attitudes towards scientists and experts in political discourse. While 'hate speech' was mentioned 12 times in the 2015 survey, it was mentioned 43 times in 2017 and 29 times in the 2019 survey. In most cases, it was discussed in relation to social media. Moreover, several responses in the surveys also linked the aggressive feedback and hate speech of laypeople to the 'bad example' set by politicians' negative commentary on researchers and their views:

\begin{abstract}
Any kind of populist commentary seems to be possible at the moment. Particularly social media seems to distance debaters from each other. A bad example of politicians seems to mean that everyone is allowed to comment on anything (64/41/2015).

When educated people, and politicians, also practice hate speech, then the ordinary people are slowly coming behind, and hate speech becomes, so to speak, generally accepted (22/35/2017).

In the name of freedom of expression, so much hate speech is allowed ... and both legislation and its implementation should be improved. It wouldn't hurt if employers were even more aware of where the border goes and what impact all this has on its targets (54/42/2019).
\end{abstract}

Online hate against researchers was thus linked with researchers being treated and portrayed by politicians as legitimate targets of frustration. By criticising and directing negative commentary towards researchers, politicians can then also portray themselves as adopting a critical view of researchers as an elite group in society whose views hamper politicians' aims and political decision-making. This trope is used to gain popular support and implement policies that might contradict research evidence. But as the responses notably highlighted, it can also foster a more general belief that researchers' views can be ridiculed or commented on aggressively. The populist gibes made by politicians and the aggressive feedback aimed at researchers can therefore be interlinked at a societal level. It was evident from the surveys that those researchers who study and communicate their expertise on issues such as immigration, ethnicity and gender have been the recipients of hostile feedback that aims to intimidate and silence them. Some respondents argued that increasing hate speech was causing self-censorship:

(I)n particular, researchers of racism, immigration and multiculturalism are threatened directly and insulted (e.g. rape threats). These kinds of threat are so abundant that they cannot be seen purely as a coincidence or as an act of individuals (12/41/2015).

Gender researchers, researchers of immigration, religion and terrorism are constantly being harassed. Many of the scientists I know have even received death threats. Female researchers have also often been subjected to rape threats and suffer from continued sexual harassment (11/33/2017).

Hate speech causes self-censorship and the public space for researchers is diminishing in many ways (11/13/2017). 
This indicates how communicating as a researcher on issues that are associated with liberal cosmopolitanism and its advancement in society can foster aggressive feedback from authoritarian populists and those who support them [e.g. Lockwood, 2018]. What is notable is that it is researchers who get labelled as 'liberal elites' due to the issues they study.

Aggressive feedback and public shaming have become more common and visible in social media. In some cases, reported in the survey, there are indications that this is not just coming from individual and often anonymous citizens, but is sometimes part of more or less organized and crowd-sourced trolling campaign against some individual researchers and the research topics they represent, such as research on asylum-seekers, racism, multiculturalism, or sex and gender.

Moreover, it also emerged from the responses that aggressive feedback on some research topics not only affects the willingness of researchers to engage in public debate as such, but also contributes to the general willingness to start or continue exploring such topics:

[...] I am not worried about myself, but younger researchers seem to avoid research topics, that do not "fit" in to this moment in time because they are afraid of hate speech $(41 / 40 / 2017)$

I have given up my trouble causing research almost completely and sought a substitutive research topic that would not be so provocative [... ] (138/37/2019)

Thus, such feedback can negatively affect in this way also the freedom of inquiry.

Academic freedom and freedom of expression are intrinsically linked, as science cannot develop without freedom of expression. The freedom to decide on the publication of research results and the right to communicate expertise in public debates are essential for academic freedom too.

Academic freedom and freedom of expression are linked through notions of the public sphere and publicity. As Robert Merton [1973] defined in his scientific norms, science is of a public and collective nature. Without critical evaluation and the testing of ideas, science is unable to develop. The principles of the public sphere are not limited to internal quality controls of science. Through public sphere, science can also become a shared property and a public good [Calhoun, 2006; Calhoun, 2009].

Our analysis of the Finnish case draws attention to how populist gibes and depreciative comments from political elites can feed into a societal sentiment of ignorance concerning research and legitimise negative and aggressive commentary towards researchers. We have highlighted how populist tendencies can entail a distancing from researchers' views and can portray researchers as elites who are alienated from the world.

The desired result of aggressive feedback, online hate and public undermining of expertise is self-censorship, where researchers remain silent for fear of the negative consequences in relation to their career and reputation. This action is 
conceptualised as a chilling effect [e.g., Kempner, 2008]. Researchers who adopt advocacy positions in public debates run the risk of being targeted by the government, large corporations, think tanks, activist groups and political parties [Lewandowsky, Mann et al., 2016].

In their study on the attitudes towards science and scientific institutions in Finland, Saarinen, Koivula and Keipi [2018] and Saarinen, Koivula and Keipi [2020] found that supporters of the Finns Party were more critical of social scientists than supporters of the Finnish liberal parties. Moreover, supporters of the Finns Party as well as those who supported the Centre Party and the National Coalition subscribed to the statement that "research funds should be targeted only at economically productive sectors" more often than their liberal counterparts. Our analysis showed that particularly social scientists studying topics such as immigration, multiculturalism, or sex and gender receive aggressive feedback aiming to intimidate them. Particularly female researchers and those who dealt with politically sensitive topics seemed to confront aggressive and sexually motivated commentary in their public appearances [cf. McDonald, Barriault and Merritt, 2020].

In analysing science-related populism [Mede and Schäfer, 2020], it is important to note that rather than representing anti-science, right-wing authoritarian populism fosters politicisation of science [Gauchat, 2012]. This is most often manifested in environmental science [e.g. Gauchat, O'Brien and Mirosa, 2017], but also in the social sciences and other fields of research closely connected to economic and political interests. Thus, science has become increasingly politically contested and ideologically connected with government regulation, factors that contribute to the politicisation of science in the public sphere. A typical populist strategy in this politicization of science, as our data shows, is labelling scientists and experts as partisans and intimidating them with shaming and trolling campaigns. Besides public shaming and aggressive feedback, unfounded claims of scientific misconduct made by activist groups are sometimes used to politicize research and make particular researchers seem dishonest [Lewandowsky and Bishop, 2016; Väliverronen and Saikkonen, 2020].

Authoritarian populist pressure and attacks towards scientists therefore notably differ from such legitimate challenging of scientific expertise in society that, for example, aims to provide other types of evidence and perspectives to complement it, or point to its shortcomings or limits [e.g. Epstein, 1998; Hess, 2011]. Authoritarian populist attacks involve blaming, disparagement and categorical labelling of scientists as biased liberal elites and partisans. The aim of these attacks is therefore to discredit the targeted scientists by portraying them, and the findings they present, as politically motivated and biased. Especially researchers studying issues associated with advancement of progressive ideas or liberal values in society face the challenge of such politically underpinned labelling and discrediting when communicating science and expertise in public arenas. Thus the concept helps to recognize and scrutinize how such politically motivated attacks may challenge science communication practices.

Under numerus authoritarian regimes, the suppression of researchers manifests in extreme forms, such as prosecution and imprisonment. However, a study of the effects of authoritarian populist tendencies to researchers' freedom of expression 
has been neglected in the context of democratic societies. Our analysis of the Finnish context offers a perspective on how relatively subtle forms of disparagement and aggressive commentary can constitute problems to freedom of expression.

Based on our analysis, it seems important to strengthen the understanding of the interrelation between populism, science and scientists' freedom of expression. This is becoming an important topic of research in the fields of science communication and public understanding of science. On the empirical side, there is certainly need for more analyses on the actual ways in which authoritarian populism functions in different countries and political cultures. Moreover, scientists' views on the effects of populist politics on science and the status of scientific expertise in society should also be mapped. In more theoretical terms, it would also be useful to consider, how pressure and attacks on science and public experts are related to the phenomenon of resisting liberal and cosmopolitan values regarding research and its public communication on issues associated with such values. Although studies scrutinizing populism in relation to science and expertise in particular have started to emerge [Mede and Schäfer, 2020] there is a need to understand better how the epistemologies of populism [Ylä-Anttila, 2018] operate in this regard. Research on these issues can also help to understand better the claimed "post-truth" condition of contemporary democratic societies by not simply approaching this phenomenon in terms of "anti-science" [e.g. Lynch, 2020], but by actually analysing how authoritarian populist pressure towards science and scientific expertise functions.

\section{References}

Aktas, V., Nilsson, M. and Borell, K. (2019). 'Social scientists under threat: resistance and self-censorship in Turkish academia'. British Journal of Educational Studies 67 (2), pp. 169-186. https://doi.org/10.1080/00071005.2018.1502872.

Arnoldi, J. (2007). 'Universities and the public recognition of expertise'. Minerva 45 (1), pp. 49-61. https://doi .org/10.1007/s11024-006-9028-5.

Berezin, M. (2013). 'The normalization of the right in post-security Europe'. In: Politics in the age of austerity. Ed. by W. Streeck and A. Schäfer. Cambridge, U.K.: Polity Press, pp. 239-261.

Butler, J. (2017). 'Academic freedom and the critical task of the university'. Globalizations 14 (6), pp. 857-861. https://doi.org/10.1080/14747731.2017.1325168.

Calhoun, C. (2006). 'The university and the public good'. Thesis Eleven 84 (1), pp. 7-43. https://doi.org/10.1177/0725513606060516.

- (2009). 'Academic freedom: public knowledge and the structural transformation of the university'. Social Research 76 (2), pp. 561-598. URL: https://www . jstor.org/stable/40972273.

Cole, J. R. (2017). 'Academic freedom as an indicator of a liberal democracy'. Globalizations 14 (6), pp. 862-868. https://doi.org/10.1080/14747731.2017.1325169.

Collins, H., Evans, R., Durant, D. and Weinel, M. (2020). Experts and the will of the people: society, populism and science. Cham, Switzerland: Palgrave Macmillan. https://doi.org/10.1007/978-3-030-26983-8.

Delborne, J. A. (2016). 'Suppression and dissent in science'. In: Handbook of academic integrity. Ed. by T. Bretag. Singapore: Springer, pp. 943-956. https://doi.org/10.1007/978-981-287-098-8_30. 
Engesser, S., Fawzi, N. and Larsson, A. O. (2017). 'Populist online communication: introduction to the special issue'. Information, Communication $\mathcal{E}$ Society 20 (9), pp. 1279-1292. https://doi.org/10.1080/1369118x.2017.1328525.

Epstein, S. (1998). Impure science: AIDS, activism, and the politics of knowledge. Berkeley and Los Angeles, CA, U.S.A.: University of California Press.

Finnish Science Barometer (2019). A study of the Finns' attitudes towards science. Tieteen tiedotus. English summary available at URL: http://www. tieteentiedo tus.fi/files/Sciencebarometer_2019_23122019.pdf.

Gauchat, G. (2012). 'Politicization of science in the public sphere: a study of public trust in the United States, 1974 to 2010'. American Sociological Review 77 (2), pp. 167-187. https://doi .org/10.1177/0003122412438225.

Gauchat, G., O'Brien, T. and Mirosa, O. (2017). 'The legitimacy of environmental scientists in the public sphere'. Climatic Change 143 (3-4), pp. 297-306. https://doi.org/10.1007/s10584-017-2015-z.

Gerbaudo, P. (2018). 'Social media and populism: an elective affinity?' Media, Culture $\mathcal{E}$ Society 40 (5), pp. 745-753. https://doi.org/10.1177/0163443718772192.

Gierth, L. and Bromme, R. (2020). 'Attacking science on social media: how user comments affect perceived trustworthiness and credibility'. Public Understanding of Science 29 (2), pp. 230-247. https://doi.org/10.1177/0963662519889275.

Grimm, J. and Saliba, I. (2017). 'Free research in fearful times: conceptualizing an index to monitor academic freedom'. Interdisciplinary Political Studies 3 (1), pp. 41-75. https://doi .org/10.1285/i20398573v3n1p41.

Hatakka, N. (2017). 'When logics of party politics and online activism collide: the populist Finns Party's identity under negotiation'. New Media \& Society 19 (12), pp. 2022-2038. https://doi.org/10.1177/1461444816660728.

Herkman, J. (2016). 'Construction of populism: meanings given to populism in the Nordic press'. Nordicom Review 37 (s1), pp. 147-161. https://doi.org/10.1515/nor-2016-0029.

Herkman, J. and Matikainen, J. (2017). 'Neo-populist scandal and social media: the Finnish Olli Immonen affair'. In: Political scandal, corruption, and legitimacy in the age of social media. Ed. by K. Demirhan and D. Çakir-Demirhan. Hershey, PA, U.S.A.: IGI Global, pp. 1-24. https://doi.org/10.4018/978-1-5225-2019-1.ch001.

Hess, D. J. (2011). 'To tell the truth: on scientific counterpublics'. Public Understanding of Science 20 (5), pp. 627-641. https://doi.org/10.1177/0963662509359988.

Hoepner, J. E. (2017). “You need to shut up': research silencing and what it reveals about academic freedom'. Ph.D. Thesis. Canberra, Australia: Australian National University. https://doi .org/10.25911/5d690afdaf719.

Ignatieff, M. (2018). 'Academic freedom from without and within'. In: Academic freedom: the global challenge. Ed. by M. Ignatieff and S. Roch. Budapest, Hungary: CEU Press, pp. 1-10.

Jungar, A.-C. (2016). 'From the mainstream to the margin? The radicalization of the true Finns'. In: Radical right-wing populist parties in Western Europe: into the mainstream? Ed. by T. Akkerman, S. de Lange and M. Rooduijn. London, U.K.: Routledge, pp. 113-143.

Kangas, O. and Kalliomaa-Puha, L. (2017). Austerity measures in Finland. ESPN Flash Report 2017/28. Brussels, Belgium: European Commission. 
Kempner, J. (2008). 'The chilling effect: how do researchers react to controversy?' PLoS Medicine 5 (11), e222. https: //doi.org/10.1371/ journal .pmed. 0050222.

Krimsky, S. (2003). Science in the private interest: has the lure of profits corrupted biomedical research? Lanham, MD, U.S.A.: Rowman \& Littlefield Publishers.

Kuehn, R. R. (2004). 'Suppression of environmental science'. American Journal of Law \& Medicine 30 (2-3), pp. 333-369. https://doi.org/10.1177/009885880403000210.

Laclau, E. (2005). On populist reason. London, U.K.: Verso.

Lewandowsky, S. and Bishop, D. (2016). 'Research integrity: don't let transparency damage science'. Nature 529 (7587), pp. 459-461. https://doi.org/10.1038/529459a.

Lewandowsky, S., Mann, M. E., Brown, N. J. L. and Friedman, H. (2016). 'Science and the public: debate, denial, and skepticism'. Journal of Social and Political Psychology 4 (2), pp. 537-553. https://doi .org/10.5964/jspp.v4i2.604.

Lockwood, M. (2018). 'Right-wing populism and the climate change agenda: exploring the linkages'. Environmental Politics 27 (4), pp. 712-732. https://doi.org/10.1080/09644016.2018.1458411.

Lynch, M. (2020). 'We have never been anti-science: reflections on science wars and post-truth'. Engaging Science, Technology, and Society 6, pp. 49-57. https://doi.org/10.17351/ests2020.309.

Martin, B. (1999). 'Suppression of dissent in science'. In: Research in social problems and public policy. Ed. by W. R. Freudenburg and T. I. K. Youn. Vol. 7. Stamford, CT, U.S.A.: JAI Press, pp. 105-135.

- (2001). 'Science: contemporary censorship'. In: Censorship: a world encyclopaedia. Ed. by D. Jones. Vol. 4. London, U.K.: Fitzroy Dearborn, pp. 2167-2170.

Mazzoleni, G. (2003). 'The media and the growth of neo-populism in contemporary democracies'. In: The media and neo-populism: a contemporary comparative analysis. Ed. by G. Mazzoleni, J. Stewart and B. Horsfield. Westport, CT, U.S.A.: Praeger, pp. 1-20.

McDonald, L., Barriault, C. and Merritt, T. (2020). 'Effects of gender harassment on science popularization behaviors'. Public Understanding of Science 29 (7), pp. 718-728. https://doi.org/10.1177/0963662520946667.

Mede, N. G. and Schäfer, M. S. (2020). 'Science-related populism: conceptualizing populist demands toward science'. Public Understanding of Science 29 (5), pp. 473-491. https://doi.org/10.1177/0963662520924259.

Merton, R. K. (1973). The sociology of science. Chicago, U.S.A.: University of Chicago Press.

Michaels, D. (2008). Doubt is their product: how industry's assault on science threatens your health. New York, NY, U.S.A.: Oxford University Press.

Mudde, C. (2007). Populist radical right parties in Europe. Cambridge, U.K. and New York, NY, U.S.A.: Cambridge University Press. https://doi.org/10.1017/CB09780511492037.

- (2017). 'Populism: an ideational approach'. In: The Oxford Handbook of Populism. Ed. by C. Rovira Kaltwasser, P. Taggart, P. Ochoa Espejo and P. Ostiguy. Oxford, U.K.: Oxford University Press, pp. 27-47. https://doi.org/10.1093/oxfordhb/9780198803560.013.1.

Norris, P. and Inglehart, R. (2019). Cultural backlash: Trump, Brexit, and authoritarian populism. Cambridge, U.K.: Cambridge University Press. https://doi.org/10.1017/9781108595841. 
Oreskes, N. and Conway, E. M. (2011). Merchants of doubt: how a handful of scientists obscured the truth on issues from tobacco smoke to global warming. New York, NY, U.S.A.: Bloomsbury Press.

Özkirimli, U. (2017). 'How to liquidate a people? Academic freedom in Turkey and beyond'. Globalizations 14 (6), pp. 851-856. https://doi.org/10.1080/14747731.2017.1325171.

Palonen, E. (2018). 'Finland: political development and data for 2017'. European Journal of Political Research Political Data Yearbook 57 (1), pp. 92-97. https://doi.org/10.1111/2047-8852.12219.

Patana, P. (2020). 'Changes in local context and electoral support for the populist radical right: evidence from Finland'. Party Politics 26 (6), pp. 718-729. https://doi.org/10.1177/1354068818810283.

Post, R. C. (1998). 'Censorship and silencing'. In: Censorship and silencing: practices of cultural regulation. Ed. by R. C. Post. Los Angeles, CA, U.S.A.: Getty Research Institute Publications, pp. 1-16.

- (2012). Democracy, expertise, and academic freedom: a First Amendment jurisprudence for the modern state. New Haven, CT, U.S.A. and London, U.K.: Yale University Press.

Saarinen, A., Koivula, A. and Keipi, T. (2018). 'Eri puolueiden kannattajien suhtautuminen suomalaiseen tieteeseen ja tutkimukseen'. Tiedepolitiikka 43 (1), pp. 18-31.

- (2020). 'Political trust, political party preference and trust in knowledge-based institutions'. International Journal of Sociology and Social Policy 40 (1/2), pp. 154-168. https://doi .org/10.1108/ijssp-06-2019-0113.

Scholars at Risk (2017). Free to think. Report of the Scholars at Risk Academic Freedom Monitoring Project. New York, NY, U.S.A. URL: https ://www. scholar satrisk.org/wp-content/uploads/2017/09/Free-to-Think-2017.pdf.

- (2018). Free to think. Report of the Scholars at Risk Academic Freedom Monitoring Project. New York, NY, U.S.A. URL: https://www . scholarsatrisk . org/wp-content/uploads/2018/10/Free-to-Think-2018.pdf.

- (2020). Free to think. Report of the Scholars at Risk Academic Freedom Monitoring Project. New York, NY, U.S.A.

URL: https://www. scholarsatrisk.org/wp-content/uploads/2020/11/Schol ars-at-Risk-Free-to-Think-2020.pdf.

Silverman, D. (2015). Interpreting qualitative data. London, U.K.: SAGE Publications.

Väliverronen, E. (2021). 'Mediatisation of science and the rise of promotional culture'. In: Routledge handbook of public communication of science and technology. Ed. by M. Bucchi and B. Trench. 3rd ed. London, U.K.: Routledge.

Väliverronen, E., Laaksonen, S.-M., Jauho, M. and Jallinoja, P. (2020). 'Liberalists and data-solutionists: redefining expertise in Twitter debates on coronavirus in Finland'. JCOM 19 (05), A10. https: //doi .org/10.22323/2.19050210.

Väliverronen, E. and Saikkonen, S. (2020). 'Freedom of expression challenged: scientists' perspectives on hidden forms of suppression and self-censorship'. Science, Technology, \& Human Values. https://doi.org/10.1177/0162243920978303.

Weingart, P. (1998). 'Science and the media'. Research Policy 27 (8), pp. 869-879. https://doi .org/10.1016/S0048-7333(98)00096-1. 
Weingart, P. (2012). 'The lure of the mass media and its repercussions on science'. In: The sciences' media connection - Public communication and its repercussions. Ed. by S. Rödder, M. Franzen and P. Weingart. Dordrecht, Netherlands: Springer, pp. 17-32. https://doi.org/10.1007/978-94-007-2085-5_2.

Wodak, R. (2015). The politics of fear. What right-wing populist discourses mean. London, U.K.: SAGE Publications.

Ylä-Anttila, T. (2018). 'Populist knowledge: 'post-truth' repertoires of contesting epistemic authorities'. European Journal of Cultural and Political Sociology 5 (4), pp.356-388. https://doi.org/10.1080/23254823.2017.1414620.

Authors

Esa Väliverronen is a professor of media and communication studies at the University of Helsinki, Faculty of Social Sciences. He has specialized in media studies and science and technology studies. He has published extensively on public discourses of science, technology and expertise in society. His recent projects focus on expertise, health and environmental issues. E-mail: esa.valiverronen@helsinki.fi.

Sampsa Saikkonen is a Postdoctoral Researcher in media and communication studies at the University of Helsinki, Faculty of Social Sciences. His research interests and publications are primarily in science and technology studies, sociology of expertise, and public communication of science and medicine. E-mail: sampsa.saikkonen@helsinki.fi.

\section{How to cite}

Väliverronen, E. and Saikkonen, S. (2021). 'Science communicators intimidated: researchers' freedom of expression and the rise of authoritarian populism'. JCOM 20 (04), A08. https:/ / doi.org/10.22323/2.20040208. 